\title{
IDEOLOGY IN THE CAMPAIGN PROGRAMMES OF PORTUGUESE POLITICAL PARTIES: THE 2009 EUROPEAN ELECTIONS
}

Paula do Espírito Santo

\section{Resumo}

Esta contribuição centra-se nas mensagens dos programas dos partidos concorrentes às eleições europeias durante a campanha eleitoral de 2009. O conteúdo dos programas dos partidos eleitorais reflete sua importância política e ideológica e serve como uma base fundamental para a compreensão do lugar e posições relativamente ao seu projeto para o desenvolvimento do Estado. A importância dos programas dos partidos eleitorais é evidente a partir do que eles refletem ou deveriam refletir, em termos de conceito político do Estado a nível nacional, bem como, a partir de uma perspectiva política mais ampla, na Europa e em termos internacionais. O ponto de partida para esta pesquisa é o pressuposto de que a ideologia é uma categoria política fundamental, apesar de sua perda de impacto e de relevância social e política em Estados democráticos ocidentais, pelo menos desde finais dos anos sessenta. Esta análise da pesquisa considera como corpus de trabalho os programas dos cinco principais partidos políticos portugueses na campanha para as eleições europeias de 2009. Este estudo socorre-se da aplicação da técnica de análise de conteúdo ao programa partidos políticos (com representação parlamentar nacional) para eleições europeias de 2009 e incide sobre a ideologia como uma categoria central, bem como sobre vários outros importantes conceitos políticos básicos nos programas a analisar. Os resultados incidirão sobre a importância da ideologia e dos valores políticos dos principais partidos políticos Portugueses em relação às suas propostas, a sua visão e seus projetos para o Estado português, bem como no plano da representação europeia.

Palavras-chave: Ideologia; Valores Políticos; Campanha Política; Mensagem nos Programas Políticos; Partidos Políticos; Eleições.

\begin{abstract}
This contribution is focused upon the electoral campaign programme messages of the political parties competing for the 2009 European elections. The contents of the parties' electoral programmes reflect their political and ideological importance and serve as a fundamental basis for understanding each parties place and positions concerning their project for developing the State. The importance of the parties' electoral programmes is evident from what they reflect, or should reflect, in terms of their political concept of the State in national terms as well as, from a broader political perspective, in European and in international terms. The starting point for this research is the assumption that ideology is a fundamental political category, though its loss of impact and of social and political relevance in Western democratic States, at least since late sixties. This research analysis as a working corpus considers the programmes of the five most representative Portuguese political parties campaigning for the 2009 European Elections. This study is based upon applying content analysis
\end{abstract}




\section{DOSSIÊ OPINIÃO PÚBLICA, ELEIÇÕES E PARTICIPAÇÃO POLÍTICA NAS DEMOCRACIAS CONTEMPORÂNEAS}

technique to the programme contents of Portuguese political parties (political parties with national Parliamentary representation) for the 2009 European elections and it will focus upon ideology as a central category as well as upon several other key political concepts basic to the programmes being analysed. The expected results will focus upon the importance of ideology and of political values of the principal Portuguese political parties in relation to their proposals, their vision and their projects for the Portuguese State as well as European representation.

Keywords: Ideology; Political Values; Political Campaign; Political Programme Messaging; Political Parties; Elections.

\section{Introductory Note}

Finding out how ideology is interpreted politically for European election campaign purposes may open new perspectives about both its application and future. This study aims to analyse the extent to which ideology still matters politically in the European campaign message programme. According to Sartori (1969, p. 398) "the word ideology points to a black box" which means that in terms of content it is wide enough to include a range of propositions that are intrinsically and mutually exclusive such as "truth and error, universality and particularity, wisdom and ignorance". Despite the accepted 'ambiguity' inherent within the concept of ideology and the "lack of agreement regarding even the basic properties of ideology" (MULLINS, 1972, p. 498) the present discussion about the importance of ideology in political messages originally looks for and aims to focus upon signs of strength, impact and differentiation. However, the data that has been considered, generally, includes a wide range of information which is very factual and of political value but scarcely anchored in ideological terms. Even with this methodological and substantive restriction this analysis looks for the pragmatism of ideology in European political programme messaging. The collected empirical data has been segmented using the content analysis technique considering a categories approach and an inferential interpretation because of its lack of expression and of political importance.

\section{The electoral context}

The 2009 European elections occurred in a very competitive year for Portugal, in electoral terms, as there were three elections during a four month time span, beginning on the $7^{\text {th }}$ of June (with the European Parliamentary elections) and ending on the $11^{\text {th }}$ of October (with the local elections). In the meantime portuguese parliamentary elections took place on the $27^{\text {th }}$ of September, 2009 and were themselves impressive, when considering both the number of parties who campaigned, a total of 15 being represented, and also 
the intensity of the media coverage ${ }^{1}$.

The Portuguese electoral system, on a national scale, is based upon two principal sovereign institutions which are the President and Parliament. The Parliamentary elections allow the country's 308 Councils to be represented at a national Assembly composed of $230 \mathrm{MPs}$, who also represent Portuguese emigrants both within and outside Europe (4 MPs being assigned to this office). The allocation of the 230 Parliamentary seats is arrived at by applying the Hond't method, based on a proportional distribution of seats.

The Portuguese electoral law envisages a 13 day period for campaign activities for all types of elections except those for the European Parliament, in which case the period is 12 days. However, most parties begin their political campaigns several weeks, sometimes months, before Election Day. The first campaign activities aimed at the European Elections in Portugal were less intense and experienced little media coverage in comparison to the Portuguese Parliamentary elections. In the case of these later elections the campaign started at the end of August (the summer holiday period), with several initiatives having been undertaken by the five major political parties. In the case of the European elections the political campaign message wasn't clearly autonomous, as would be the case in two further successive elections. The length of the European elections was far more visible in terms of the socalled pre-campaign, about one month before the Election Day.

were as follows:

The national results for the 2009 and the 2004 European Elections

${ }^{1}$ For the 2009 Parliamentary elections see: Espírito Santo (2010).

REVISTA DEBATES, Porto Alegre, v. 5, n. 2, p. 41-54, jul.-dez. 2011. 


\section{DOSSIÊ OPINIÃO PÚBLICA, ELEIÇÕES E PARTICIPAÇÃO POLÍTICA NAS DEMOCRACIAS CONTEMPORÂNEAS}

Table 1 - Results of the 2009 versus the 2004 European elections in Portugal

\begin{tabular}{l|c|c|cc}
\hline Political party & $\begin{array}{c}\text { \% (N.er votes) } \\
\mathbf{2 0 0 9}\end{array}$ & $\begin{array}{c}\text { \% (N.er votes) } \\
\mathbf{2 0 0 4}\end{array}$ & $\begin{array}{c}\text { N.er seats } \\
\mathbf{2 0 0 9} \text { versus } \\
\mathbf{2 0 0 4}\end{array}$ \\
\hline PPD/PSD (2004+CDS-PP) & $31.71(1129243)$ & $33.27(1133647)$ & 8 & 9 \\
\hline PS & $26.58(946475)$ & $44.53(1517282)$ & 7 & 12 \\
\hline BE & $10.73(382011)$ & $4.91(167286)$ & 3 & 1 \\
\hline PCP-PEV & $10.66(379707)$ & $9.08(309421)$ & 2 & 2 \\
\hline CDS/PP & $8.37(298057)$ & - & 2 & - \\
\hline MEP & $1.48(52828)$ & - & - \\
\hline PCTP/MRPP & $1.21(43141)$ & $1.06(36139)$ & - \\
\hline PND & - & $1(34047)$ & - \\
\hline MPT & $0.66(23415)$ & $0.4(13647)$ & - \\
\hline PHS & $0.61(21636)$ & - & - \\
\hline MD & $0.48(16980)$ & $0.39(13225)$ & - \\
\hline PPM & - & $0.41(13821)$ & - \\
\hline PNR & $0.39(13794)$ & $0.46(15513)$ & - \\
\hline PDA & $0.37(13039)$ & $0.24(8131)$ & - \\
\hline POUS & - & $0.17(5588)$ & - \\
\hline Blank votes & $0.14(5101)$ & $0.13(4315)$ & - \\
\hline Invalid votes & $4.63(164917)$ & $2.56(87268)$ & - \\
\hline Electors & $2(71158)$ & $1.42(48372)$ & - \\
\hline Voters & 9684714 & 8812081 & - \\
\hline
\end{tabular}

Note: In 2004, the total of Portuguese represented seats in the EU Parliament was 24. There was a loss of 2 seats for 2009, due to the new arrangements in EU representation resulting from the new member countries and the Lisbon Treaty.

Source: DGAI (2009).

Considering the 2004 European elections, the Socialist Party (PS), the party in Government (which won the 2009 elections in September, thereby renewing its mandate) lost 5 seats in the EU Parliament (having previously had 12). The PPD/PSD (Partido Popular Democrático/Partido Social Democrático - Popular Democratic Party/Social Democratic Party) in coalition with the CDS/PP (Centro Democrático Social/Partido Popular - Popular Democratic Centre/Popular Party) had 9 seats in 2004. In 2009 the PSD gained 8 and the CDS/PP 2 seats, respectively. The PCP/PEV (Partido Comunista Português/Partido Ecológico Os Verdes - Portuguese Communist Party/Ecological Green Party) had 2 seats in 2004 and maintained them in 2009. The BE (Bloco de Esquerda - Left Bloc), a Marxist-Trotskyist party gained 2 seats in 2009 (having had 1 in 2004).

The European Parliament is made up of seven families or political groups $^{2}$. There are two leading groups which are centre-right conservatives

\footnotetext{
${ }^{2}$ This is the composition of the groups at the $7^{\text {th }}$ European Parliament. Each mandate has a five
} 
and Christian Democratic parties, the 'European People's Party' - EPP (which includes the PSD and the CDS/PP), consisting of 265 MEPs and the 'Progressive Alliance of Socialists and Democrats' (S\&D) (which includes the Portuguese PS representation), consisting of 184 MEPs. Apart from these two leading groups the EU Parliament includes five other important political forces which are: the 'Alliance of Liberals and Democrats for Europe' (ALDE) (with 84 MEPs); the 'Greens/European Free Alliance' (Greens-EFA) (with 55 MEPs); the 'European Conservatives and Reformists' (ECR) (with 54 MEPs); the 'European United Left/Nordic Green Left' (GUE-NGL) (where BE and PCP-PEV are represented) (with 35 MEPs) and the 'Europe of Freedom and Democracy' (EFD) (with 31 MEPs) ${ }^{3}$. The European system is one of proportional representation and follows the previous of each State, though each State has to have a proportional base whether supported by party lists or by a unique transferable vote system ${ }^{4}$.

\section{Methodology: the application of the content analysis technique}

Content analysis is the technique on which this study is based in methodological terms. After applying content analysis technique to social sciences, this research was supported by traditional contributions (BERELSON and SALTER, 1946; BERELSON and GRAZIA, 1947; BERELSON, 1952; BARDIN, 1991，2001; KRIPPENDORF， 1986) as well as from further contributions that have provided important improvements to its application, generally, in methodological terms (WEBER, 1990; ROMERO, 1991; ALTHEIDE, 1996) and, specially, when considering how it was applied to politics (KERNELL, 1997; LE BART, 1998; LAVER, BENOIT and GARRY, 2003; BRADSHAW, 2004; SALAVASTRU, 2005; SANTULLU, 2005; ESHBAUGH-SOHA, 2006; NICOT et alia, 2007; ESPÍRITO SANTO, 2008).

Ideology is the key-concept of this research which will be segmented and expressed under several categories constructed by following either a so called 'miles' process (BARDIN, 1991, 2001) or by using previous contributions developed using this technique applied to political purposes and similar bodies of analysis (ESPÍRITO SANTO, 2008). Semantically next to the key-concept of 'ideology' the categories 'socio-political values' and 'political values' were also taken into consideration and constructed based upon previous research with a common methodological basis and applied to similar

term. Since 1979 the MEPs are directly elected, being one of the oldest common institutions having been founded as early as 1952 as the Common Assembly of the European Coal and Steel Community (ECSC).

3 Each of these Groups includes sub-parties. The current number of seats in the European Parliament is 751 (and has been since 2009 and the Lisbon Treaty). In 2008 there were 736 seats (due to the Nice Treaty) and in 2007 there were 785.

4 The smaller countries have a greater number of delegates than the number that should be previewed proportionally, which is consequent to concrete negotiations with each State member. 


\section{DOSSIÊ OPINIÃO PÚBLICA, ELEIÇÕES E PARTICIPAÇÃO POLÍTICA NAS DEMOCRACIAS CONTEMPORÂNEAS}

political propaganda materials (ESPÍRITO SANTO, 2008). The category of socio-political values includes basic key ideas that do not have a direct ideological connotation and are widely used whether in social or in political terms as basic concepts that support the functions and structures of society (eg. youth, confidence, justice, solidarity and so on). What is meant in relation to the political values is a range of expressions that symbolically have been used in political terms by parties or political agents and that are directly or indirectly connected to a broader and more national vision of how the State functions (eg. Equality, nationalism and national cohesion, stability, democracy and so on). Ideology as a category includes all the expressions that indicate a doctrinarian position in political terms that can be sufficiently distinctive among the ideological quadrants several various parties (eg. Right, left, socialism, conservatism, liberalism and neoliberalism).

Validity is in its essence achieved by a clear demonstration of the necessary steps to undertake this research (BRINGBERG and MCGRATH, 1985). The validity of the present methodological research process was assured throughout the various phases of the categories and the indicators and the means in which they were constructed, essentially by exposing clearly concrete hypothesis that would lead the way of the research (see below). This was achieved by assuring that an exhaustive approach was taken when constructing the categories and the indicators in order to assure that the results obtained would be both redundant and adequate either to serve the aims of the research or of the characteristics of the materials. The correspondent indicators of those three categories being considered were constructed considering a criterion of mutual exhaustiveness as well as by making the greatest effort to represent both the political sense and the prevalent message of each of the items considered in the body of analysis used as a basis of this research. The category indicators can be seen below in Table 2. For obvious reasons an indicator known as 'Europe' was not included in the results analysis as its use was self-evident within the analysed political messages which, as previously mentioned, were directed towards the European campaign elections.

Some new indicators were added after taking into consideration the previous research quoted (ESPÍRITO SANTO, 2008), referred to above, and were applied to national political propaganda materials which included 'security', 'equality', 'conservadorism', 'liberalism and neoliberalism'. These key words allowed for concrete definitions of the 'political' and 'ideological' value categories and clearly contributed in showing a more defined position in terms of the political vision of the parties competing for the European elections in order to capture its electorate.

The analyses segments which were taken into account were 'word' and 'issue'. 'Presence' was considered as a registration unit. Frequency, although usually found in content analysis research, has not been used here. The reason why frequency has not been adopted in this research is that even 
though the body of analysis extends, in some cases, to several pages it would seldom reflect redundancy in terms of key words or issues.

The hypotheses constructed are centred upon both the key concept and idea of 'ideology' and of the prevalent political values of the messages under analysis and are as follows:

- While national interest is the key concept and idea of the PSD programme, reflecting Europe as a context category and a non-explicit ideological anchor, in the PS programme Europe is the central concept and a clear left-sided ideological position exists.

- The PS has a programmatic message anchored in detailed measures and concepts that envisage a clear ideological defence of political values.

- Despite belonging to the same European Group (the EPP), the PSD and the CDS do not defend or quote the same fundamental key concepts and ideas, as expressed in their programmes. The opposite occurs with the BE and the PCP where they belong to the same European Group and are convergent in their political and ideological values.

- $\quad$ The left wing parties (PS, BE and PCP/PEV) reflect a clearer and more frequent ideological position, in programmatic terms. The position of ideology is not evident in the right wing parties (PSD and CDS/PP), despite the presence of concrete political measures.

\section{Presentation and discussion}

Political programmes are among the most important political sources of information for a significant part of electors, which has been seen concerning the European elections (CAYROL, 1989). It means that the final decision to vote can be taken in relation to the contents of a political programme. This point is particularly relevant if we especially consider the role of the campaign and the publicity of the political programmes for the Parliament elections as an important element in appealing for greater proximity between European institutions and their citizens, moreover when considering the traditional low electoral turnout in Parliamentary elections.

The political programmes analysed differed greatly from one another in terms of general shape and form with regard to both the number of pages and their image content. The PPD/PSD political programme entitled "For the National Interest - A European Contract with the Portuguese People" which was part of the slogan "Politics of Truth" was the shortest in length (four pages) and the last to come under public opinion. Its political position generally outlined in its first line the need for national interest and national structural as political priorities. The PS programme was the longest (at 32 pages) of the five analysed and was also attractive in terms of visual quality but overly detailed and too long. It was titled "The people first - a New Direction for Europe". It is important to note that the PS did not win these 


\section{DOSSIÊ OPINIÃO PÚBLICA, ELEIÇÕES E PARTICIPAÇÃO POLÍTICA NAS DEMOCRACIAS CONTEMPORÂNEAS}

elections, finishing only second. This was very much due to being both the party in Government that was naturally punished but also due to what we consider the effect of not having an appealing campaign leader. The leader (a former PCP party supporter and activist) performed poorly during the campaign (some incidents also occurred in relation to this head party list). Its position has generally been positive and pro-Europe. The BE programme called "Electoral compromise" was poor in visual terms and took up 14 pages. The political European position and tone which it adopted was critical of the European basis of the project. The PCP-PEV programme, 16 pages in length and also poor in visual terms (like the majority of its rivals it's on line version was poorly structured and was not at all visually attractive). The PCP-PEV was named "PCP Programmatic Declaration". The CDS/PP programme was six pages long and also poor in its graphic presentation. It was called "European Politics, External Affairs and Emigration". Its contents were greatly developed upon the idea of the importance of external affairs as well as international and European issues.

Table 2 - Summary of the socio-political, ideological and political representations of the programmes of the principal Portuguese candidates for the 2009 European elections

\begin{tabular}{|c|c|c|c|c|c|c|c|c|c|c|c|c|c|c|c|c|}
\hline & \multicolumn{16}{|c|}{ CATEGORIES } \\
\hline & \multirow{2}{*}{\multicolumn{6}{|c|}{ Socio-political values }} & \multirow{2}{*}{\multicolumn{5}{|c|}{ Political values }} & \multicolumn{5}{|c|}{ Ideology } \\
\hline & & & & & & & & & & & & & & & & \\
\hline & 1 & 2 & 3 & 4 & 5 & 6 & 7 & 8 & 9 & 10 & 11 & 12 & 13 & 14 & 15 & 16 \\
\hline PPD/PSD & $\checkmark$ & $\checkmark$ & $\checkmark$ & & $\checkmark$ & & $\checkmark$ & $\checkmark$ & & & $\checkmark$ & & & & & \\
\hline PS & $\checkmark$ & $\checkmark$ & $\checkmark$ & $\checkmark$ & $\checkmark$ & & $\checkmark$ & & & $\checkmark$ & $\checkmark$ & $\checkmark$ & $\checkmark$ & $\checkmark$ & $\checkmark$ & \\
\hline$\overline{\mathrm{BE}}$ & $\checkmark$ & & & $\checkmark$ & $\checkmark$ & & & $\checkmark$ & & $\checkmark$ & & $\checkmark$ & $\checkmark$ & & & $\checkmark$ \\
\hline PCP/PEV & $\checkmark$ & & $\checkmark$ & $\checkmark$ & $\checkmark$ & $\checkmark$ & $\checkmark$ & & & $\checkmark$ & $\checkmark$ & $\checkmark$ & $\checkmark$ & & $\checkmark$ & $\checkmark$ \\
\hline$\overline{\mathrm{CDS} / \mathrm{PP}}$ & & & & & $\checkmark$ & & & & $\checkmark$ & $\checkmark$ & & & & & & \\
\hline
\end{tabular}

Legend: 1. Youth; 2. Confidence; 3. Justice; 4. Solidarity; 5. Security; 6. Equality; 7. Nationalism and national cohesion; 8. Change; 9. Stability; 10. Democracy; 11. Freedom; 12. Right; 13. Left; 14. Socialism; 15 . Conservatism; 16. Liberalism and neoliberalism.

Source: Prepared by the author. 
Graph 1 - Summary of the socio-political, ideological and political representations of the programmes of the principal Portuguese candidates for the 2009 European elections

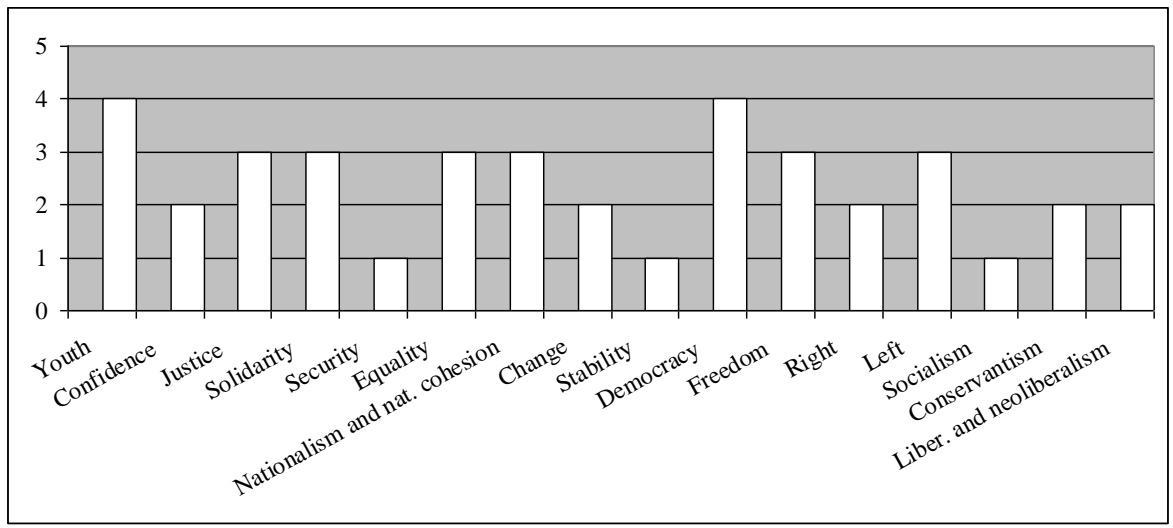

Source: Prepared by the author.

Graph 2 - Summary of the socio-political, ideological and political representations of the programmes of the principal Portuguese candidates for the 2009 European elections, comparison between right and left

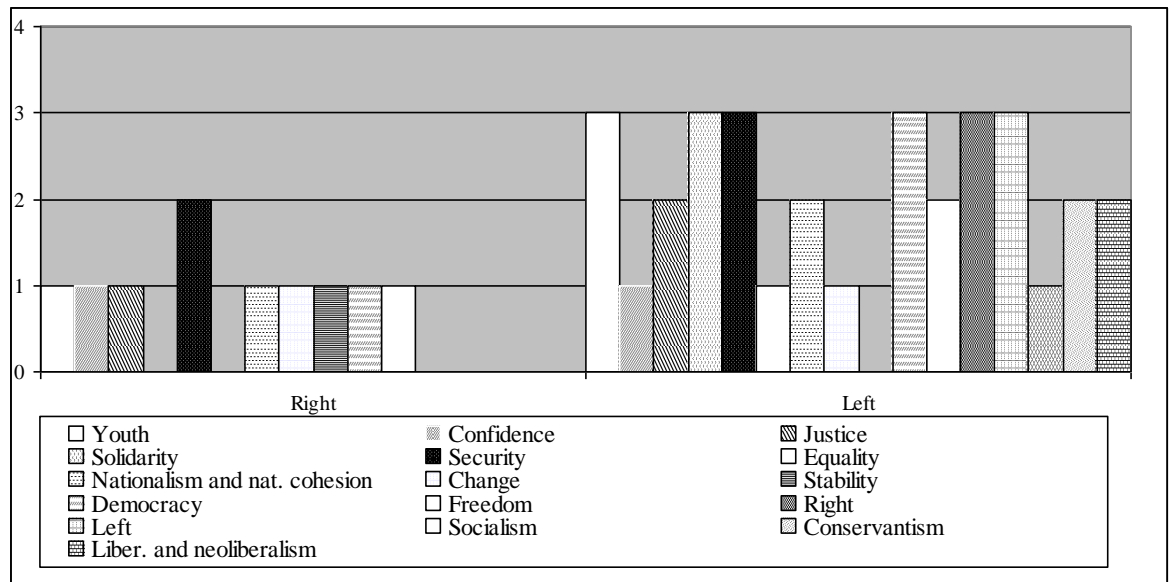

Source: Prepared by the author. 


\section{DOSSIÊ OPINIÃO PÚBLICA, ELEIÇÕES E PARTICIPAÇÃO POLÍTICA NAS DEMOCRACIAS CONTEMPORÂNEAS}

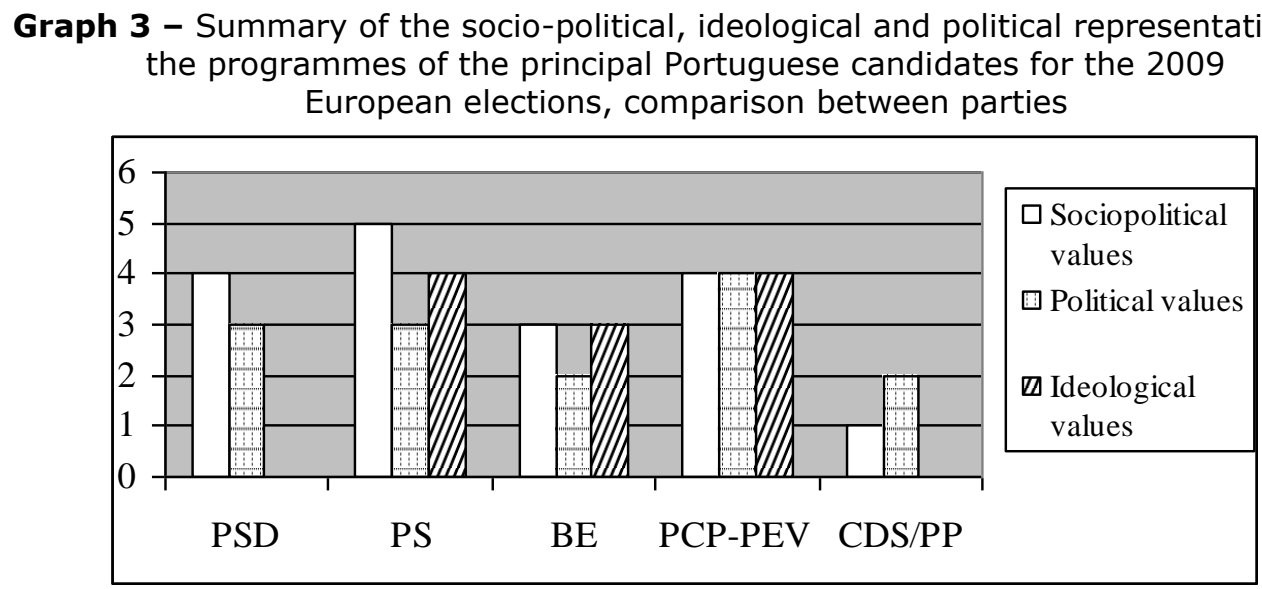

Source: Prepared by the author.

When comparing the two right wing parties it is clear that the PSD used more socio-political and political programmatic message resources than the CDS whose political programme rarely expressed range of typical political or ideological concepts used by the other parties. The usual CDS central idea is 'internal security', which was also, naturally, referred in this programme along with the central issue of external affairs along with emigration. The PSD, on the other hand, did not present an ideological programme, considering instead the key issues that were normally featured in the other parties' programmes. Of the left wing parties the most prevalent categories were youth, solidarity, security, democracy, right and left which together with the other indicators seem to indicate not only a somewhat more socio-political but also an 'ideological' programme for these parties.

It is also important to stress that the PSD like the PS (the two main contenders) used the key idea of nationalism. However, in the case of the PSD this idea was used contextually as a means of detaching the national interest. For the PS, Europe was a central idea, the basis of the programme message and was presented clearly and positively as well as ideologically to the left.

The PS programme was long and detailed both in terms of concrete measures and concepts. The PS programme is the most anchored ideologically, using specifically key indicators to cement its positions, such as 'right', 'left', 'socialism' and 'conservatism'.

Comparing the PSD and the CDS programmes it is clear that these two parties do not evoke similar concerns in relation to European issues, despite belonging to the same European Group (EPP). The mention of security as an important value for both parties is the exception. However among the range of the other values considered by the PSD or by the CDS there is no other convergence. With regard to the BE and the PCP, which are also found in the 
same group, the convergence values are more frequent than in any of the three categories considered.

From the results achieved we have conclude that ideology is still an important category in terms of the programmatic contents of the electoral programmes being considered. However, in relation to the body of work analysed the expression of ideology strictly considered through key categories and indicators is more evident in the left wing parties, regardless of observing the various positions ranging from the parties on the extreme left to the mid left. The several hypotheses formulated have though been confirmed.

Ideology is a key-concept for the political European message; however its application mainly reflects the importance of social and political impacts which citizens' favour rather than the principles and orientations on which it is strictly and ideologically based upon. According to the political messages being analysed, in electoral terms, ideology is a pragmatic concept that includes three key dimensions which are substantively connected: the sociopolitical, political and ideological representations, occurring in a series where the two first dimensions are prevalent. In other words, political communication implies a broader perspective for the interpretation of the conceptual limits of ideology. The boundaries of ideology depend upon a connection to a wide range of indicators that are politically and socially visible and expressive in communication terms.

\section{Conclusion}

In democracy, political programmes are the starting point for political action and compromise and an important basis for voters when making electoral decisions. Bearing this importance in mind political programmes can make a difference in relation to the understanding of the convergences and differences between the electoral pledges made by the principal contenders. Understanding electoral pledges allows for a better understanding of the State wide, key democratic values for a shorter mandate period, however it is long enough for one to comprehend the State's priorities in terms of several key concepts and strategies which guide the leading political parties.

This research was focused upon the importance of the electoral message, in programme terms, and was influenced by a methodology based on applying content analysis technique to those political materials. Three basic content analysis categories helped in characterizing the political programme message of each party, which were the socio-political, political and ideological values. The conclusion is that ideology is still important in terms of a political pledge. However, it is not the fundamental programme issue when compared to the remaining categories. It can be said that ideology is not even the key solution for winning elections, as was demonstrated in the 2009 European elections: the party that carried the shorter and one of the lesser or non-ideological messages was the eventual winner of the Portuguese 


\section{DOSSIÊ OPINIÃO PÚBLICA, ELEIÇÕES E PARTICIPAÇÃO POLÍTICA NAS DEMOCRACIAS CONTEMPORÂNEAS}

European Parliament elections. Left wing parties still frequently use ideology as a symbolic, distinctive and pragmatic tool. However, even in the case of these parties the socio-political and political values are competing to provide electoral solutions to the everyday problems of voters. In other words, the solutions presented by the parties based on concrete issues and problems were one of the strategies in the messages used to court electors and were as important as their ideological demarcation, in the case of the left wing parties. In the case of the right wing party's ideology was not even a consideration, if we observe a set of key, specific and distinctive ideas, and the message was focused upon socio-political and political concerns and symbolic ideas.

Paula Espírito Santo is Aggregate Professor (PhD) at Instituto Superior de Ciências Sociais e Políticas/Universidade Técnica de Lisboa.

E-mail: espsanto@iscsp.utl.pt

\section{References}

ALTHEIDE, David. Qualitative Media Analysis. Newbury Park, CA: Sage, 1996.

BARDIN, Laurence. Análise de Conteúdo. Lisboa: Edições 70, [1977] 1991. . L'Analyse de Contenu. Paris: PUF, [1977] 2001.

BERELSON, Bernard. Content Analysis in Communication Research. New York: The Free Press, 1952.

BERELSON, Bernard; GRAZIA, Sebastian de. Detecting Collaboration in Propaganda. The Public Opinion Quarterly, Oxford, v. 11, n. 2, p. 244-253, summer 1947.

BERELSON, Bernard; SALTER, Patricia J. Majority and Minority Americans: An Analysis of Magazine Fiction. The Public Opinion Quarterly, Oxford, v. 10, n. 2, p. 168-190, summer 1946.

BRADSHAW, Joel C. Who Will Vote for You and Why: Designing Campaign Strategy and Message. In: THURBER, James A.; NELSON, Candice J. (Eds.). Campaigns and Elections American Style. Boulder, C.O.: Westview Press, 2004. p. 37-56.

BRINGBERG, David; MCGRATH Joseph. Validity and the Research Process. Newbury Park, C.A.: Sage Publications, 1985.

CAYROL, Roland. Le Rôle des Campagnes Électorales. In: GAXIE, Daniel (Ed.). 
Explication du Vote, Un Bilan des Études Électorales en France. Paris: Presses de la Fondation Nationale des Sciences Politiques, 1989. p. 385-417.

DGAI - Direç̧ão Geral da Administração Interna. Ministério da Justiça. Europeias $2009 . \quad$ Available in: <http://www.legislativas2009.mj.pt/Europeias2009/>. Accessed in: 25 June 2010.

ESHBAUGH-SOHA, Matthew. The President's Speeches - Beyond "Going Public". Boulder, C.O.: Lynne Rienner Publishers, 2006.

ESPÍRITO SANTO, Paula. Estudos de comunicação política - Análise de conteúdo da mensagem na campanha e pós-campanha eleitoral nas eleições Presidenciais. Lisboa: ISCSP, 2008.

. The 2009 Portuguese Parliamentary elections. Electoral Studies, London, v. 29, n. 2, p. 279-281, jun. 2010.

KERNELL, Samuel. Going Public: New Strategies of Presidential Leadership. Washington: CQ Press, 1997.

KRIPPENDORF, Klaus. Content Analysis - An Introduction to Its Methodology. London: Sage Publications, 1986.

LAVER, Michael; BENOIT, Kenneth; GARRY, John. Extracting Policy Positions from Political Texts Using Words as Data. The American Political Science Review, Los Angeles, v. 97, n. 2, p. 311-331, may, 2003.

LE BART, Christian. Le discours politique. Paris: PUF, 1998.

MULLINS, Willard A. On the Concept of Ideology in Political Science. The American Political Science Review, Los Angeles, v. 66, n. 2, p 498-510, jun., 1972.

NICOT, Anne-Laure et alia. La Démocratie en Questions. L'usage Stratégique de Démocratie et de ses Dérivés dans les Questions au Gouvernement de la $11^{\circ}$ Législature (1997-2002). Dire la Démocratie Aujourd'hui - Mots, les Langages du Politique, Paris, n. 83, p. 9-21, mars 2007.

ROMERO, Andrés. Metodologia da Análise de Conteúdo. Lisboa: Universidade Católica Portuguesa, 1991.

SALAVASTRU, Constantin. Rhétorique et Politique: Le Pouvoirs du Discours et le Discours du Pouvoir. Paris: L'Harmatan, 2005. 
DOSSIÊ OPINIÃO PÚBLICA, ELEIÇÕES E PARTICIPAÇÃO POLÍTICA NAS DEMOCRACIAS CONTEMPORÂNEAS

SANTULLU, Francesca. Le Parole del Potere, il Potere delle Parole. Retorica e Discorso Politico. Pavia: Ed. Franco Angelli, 2005.

SARTORI, Giovanni. Politics, Ideology, and Belief Systems. The American Political Science Review, Los Angeles, v. 63, n. 2, p 398-411, jun. 1969.

WEBER, Robert Philip. Basic Content Analysis. Newbury Park, CA: Sage Publications, 1990. 